\author{
AnEta SuCHoń ${ }^{1}$
}

\title{
Dzierżawa jako popularna instytucja prawa prywatnego w rolnictwie - uwagi historyczne, stan obecny i perspektywy rozwoju
}

Dzierżawa, obok własności, stanowi tytuł prawny prowadzenia i organizowania gospodarstw rolnych. Jest coraz częściej wykorzystywana przez ustawodawcę jako instrument kształtowania struktury agrarnej czy nawet ustroju rolnego państwa ${ }^{2}$, którego podstawą według art. 23 Konstytucji są gospodarstwa rodzinne. W ich skład mogą wchodzić grunty zarówno własne, jak i dzierżawione.

Przedmiotem dzierżawy są rzeczy przynoszące pożytki. W przypadku rolnictwa to przede wszystkim grunty rolne. W praktyce można się spotkać także z dzierżawą zwierząt, głównie krów. Należy wziąć pod uwagę, z jednej strony, swoistość dzierżawy ziemi uprawnej wynikającą z właściwości przedmiotu przynoszącego pożytki naturalne, z drugiej zaś odrębności dzierżawy nieruchomości z Zasobu Własności Rolnej Skarbu Państwa będącej rezultatem sytuacji, w której wydzierżawiającym jest Krajowy Ośrodek Wsparcia Rolnictwa, czyli państwowa osoba prawna. W porównaniu z dzierżawą prywatnych gruntów rolnych swoboda stron w zakresie zawierania takich umów dzierżawy, ustalania ich warunków i wykonywania jest w dużym stopniu ograniczona. Ponadto, prócz powszechnie obowiązującego prawa, istotny wpływ na dzierżawę nieruchomości z Zasobu WRSP mają zarządzenia Dyrektora Generalnego KOWR ${ }^{3}$ czy poprzednio Wytyczne Prezesa Agencji Nieruchomości Rolnych ${ }^{4}$.

$1 \quad$ Uniwersytet im. Adama Mickiewicza w Poznaniu.

2 Zob. A. Lichorowicz, Instrumenty oddziaływania na strukturę gruntową Polski w ustawie z dnia 11 kwietnia 2003 r. o kształtowaniu ustroju rolnego, „Kwartalnik Prawa Prywatnego” 2004, nr 2, s. 398.

3 Zarządzenie Dyrektora Generalnego Krajowego Ośrodka Wsparcia Rolnictwa: 103/2017/Z z dnia 9 października 2017 roku w sprawie wydzierżawiania nieruchomości Zasobu Własności Rolnej Skarbu Państwa, zmienione zarządzeniem nr 28/2018/Z; zarządzenie nr 28/2018/Z Dyrektora Generalnego Krajowego Ośrodka Wsparcia Rolnictwa z dnia 22 lutego 2018 r. zmieniające zarządzenie nr 103/2017/Z z dnia 9 października 2017 r. w sprawie wydzierżawiania nieruchomości Zasobu Własności Rolnej Skarbu Państwa; zarządzenie nr 95/2017/Z Dyrektora Generalnego Krajowego Ośrodka Wsparcia Rolnictwa z dnia 6 października 2017 roku w sprawie wykonywania umowy dzierżawy nieruchomości Zasobu Własności Rolnej Skarbu Państwa, KOWR, [online], (data dostępu: 10.11.2018). Dostępny w Internecie: <http://www.kowr.gov.pl/zasob/dzierzawa-nieruchomosci>.

$4 \quad$ Zgodnie z $\S 16$ rozporządzenia Ministra Skarbu Państwa z dnia 1 sierpnia 2003 r. w sprawie nadania statutu Agencji Nieruchomości Rolnych do zadań Biura Prezesa należało np. opracowywanie projektów wytycznych 
Można wyróżnić dwa typy umów wykorzystywanych w ramach działania administracji: kontrakty cywilnoprawne (regulowane przepisami prawa cywilnego) oraz kontrakty publicznoprawne, zwane też administracyjnoprawnymi (regulowane przepisami prawa administracyjnego $)^{5}$. Ta ostatnia forma nie została jednak wyodrębniona w polskim systemie prawnym. W literaturze umowy publicznoprawne, w nawiązaniu do konstrukcji francuskiej, określane są jako np.: „kontrakty zawierane przez państwo i inne osoby prawne prawa publicznego zawsze z podmiotami prywatnymi i mające na celu uzyskanie dóbr lub usług o cechach użyteczności publicznej". Często wskazuje się, że umowa administracyjna regulowana jest przepisami prawa publicznego, musi wyraźnie uwzględniać interes publiczny, administracja ma przy jej kształtowaniu i ewentualnym zmienianiu więcej swobody niż strona umowy cywilnej. Spory na tle takich umów rozpatrywane są przez sądy administracyjne, a nie cywilne?

Celami artykułu są: po pierwsze, próba przedstawienia kształtowania się regulacji prawnych dotyczących instytucji dzierżawy gruntów rolnych oraz czynników mających wpływ na ten proces, a po drugie, ustalenie, w jaki sposób na zawieranie i wykonywanie dzierżawy jako instytucji prawa cywilnego wpływa fakt, że Krajowy Ośrodek Wsparcia Rolnictwa jest państwową osobą prawną.

\section{Ewolucja i kształtowanie się przepisów dotyczących dzierżawy}

Na ziemiach polskich dzierżawa gruntów rolnych zaczęła być szerzej wykorzystywana w XIX w. w związku z przeprowadzanymi wtedy reformami dotyczącymi przede wszystkim zniesienia poddaństwa i uwłaszczenia chłopów. Reformy te rozciągnięte były w czasie i przeprowadzone zostały w różny sposób, zależnie od sytuacji gospodarczej i politycznej panującej w poszczególnych zaborach ${ }^{8}$.

Przepisy prawne dotyczące gospodarowania na dzierżawionych gruntach rolnych zawarte zostały w Kodeksie Napoleona, wprowadzonym 1 maja 1808 r. ${ }^{9}$ w Księ-

i procedur dotyczących gospodarowania mieniem Zasobu w formach przewidzianych w ustawie z dnia 19 października 1991 r., a więc także w formie dzierżawy (Dz.U. z 1991 r. nr 140, poz. 1348 z późn. zm.).

$5 \quad$ I. Lipowicz, Prawne formy działania administracji publicznej - między stabilizacją a potrzebą przełomu, „Ruch Prawniczy, Ekonomiczny i Socjologiczny” 2016, z. 4, Rok LXXVIII, s. 45 i n. i literatura tam podana; M. Wierzbowski (red.), Prawo administracyjne, wyd. 12, Warszawa 2015, s. 19 i n; M. Wierzbowski, Prawne formy działania administracji. Porozumienie administracyjne, (w:) idem (red.), op. cit., s. 272 i n.; S. Prutis, Instytucje podstawowe prawa prywatnego, Białystok 2018, s. 92 i n.

$6 \quad$ Ibidem; I. Lipowicz, Prawne formy działania administracji..., op. cit., s. 45 i n.

7 J. Łętowski, Umowy, pertraktacje, uzgodnienia, „Rzeczpospolita” z dnia 18 listopada 1993 r.; Umowa jako forma prawna działania administracji, [online]. Pozew [data dostępu: 22.11.2018). Dostępny w Internecie: <http://www. pozew.pl/694-umowa-jako-forma-prawna-dzialania-administracji>.

Szerzej na temat reform XIX w. np.: B. Tańska-Hus, Dzierżawa rolnicza jako instrument przekształceń strukturalnych w rolnictwie, Wrocław 2000, s. 11-12; W. Pańko, Dzierżawa gruntów rolnych, Warszawa 1975, s. 162-163; A. Stelmachowski, B. Zdziennicki, Prawo rolne, Warszawa 1987, s. 65 i n.

9 Dekret Króla Saskiego i Księcia Warszawskiego z 27 stycznia 1808 r. nakazujący wprowadzenie Kodeksu Napoleona, Dz. Pr. Ks. War. t. I, s. 46. 
stwie Warszawskim ${ }^{10}$. Obowiązywały one później w Królestwie Polskim ${ }^{11}$. Artykuł $1711 \mathrm{KN}^{12}$ określał dzierżawę jako najem nieruchomości wiejskich ${ }^{13}$. Była ona zatem traktowana jako rodzaj wynajmu ${ }^{14}$. Zgodnie z definicją zawartą w art. 1709 wymienionego aktu prawnego najem rzeczy był umową, na podstawie której jedna ze stron zobowiązywała się przekazać drugiej używanie rzeczy przez pewien czas i za pewną cenę, jaką druga strona zobowiązywała się zapłacić. Umowa dzierżawy mogła być zawarta na piśmie lub ustnie ${ }^{15}$. Według art. $1774 \mathrm{KN}$ dzierżawę gruntu wiejskiego zawartą bez formy pisemnej poczytywano za zawartą na czas potrzebny do zebrania przez dzierżawcę wszelkich płodów z danej nieruchomości. Dzierżawa łąk, winnic i innych gruntów, z których płody zbierane są w całości w ciągu roku, uznawana była za zawartą na dwanaście miesięcy. Dzierżawa gruntów ornych podzielonych na pola lub zmiany (chodzi o stosowanie płodozmianu) uważana była za zawartą na tyle lat, ile było pól.

Jeżeli chodzi o regulacje dzierżawy gruntów rolnych obowiązujące na ziemiach polskich na początku XIX w., na uwagę zasługuje niemiecki kodeks cywilny z 18 sierpnia 1896 r. ${ }^{16}$ Według $§ 581$ tego kodeksu ,....kontraktem dzierżawnym zobowiązuje się wydzierżawiającego do oddania dzierżawcy wydzierżawionego przedmiotu na czas dzierżawy w celu używania i zbierania owoców, o ile je według zasad prawidłowego gospodarowania jako dochód uważać należy. Dzierżawca obowiązany był opłacać wydzierżawiającemu umówiony czynsz"17. W sprawach nieuregulowanych w $§ 582-597 \mathrm{kc}$. do dzierżawy stosowało się przepisy o najmie.

Po I wojnie światowej przepisy dotyczące dzierżawy zawarto w Kodeksie zobowiązań z 1933 r. Miały one zastosowanie do wszystkich rodzajów umów najmu. Warto podkreślić, że dzierżawa gruntów rolnych regulowana była przez szereg przepisów szczególnych, skierowanych tylko do niektórych grup dzierżawców. Stosowne przepisy zostały zawarte w kodeksie zobowiązań w art. 402-418 ${ }^{18}$. Według art. 402 kz. przez umowę dzierżawy wydzierżawiający zobowiązywał się przekazać

10 Kodeks Napoleona, Warszawa 1813, s. 421-437. Na temat Kodeksu Napoleona zob. zwłaszcza J. Bardach, B. Leśnodorski, M. Pietrzak, Historia państwa i prawa polskiego, Warszawa 1976, s. 426-427; K. Sójka-Zielińska, Wielkie kodyfikacje cywilne XIX wieku, Warszawa 1970, s. 154-157.

11 Kodeks Cywilny Królestwa Polskiego z 1825 r. nie wprowadził nowych regulacji poświęconych dzierżawie. W zakresie dzierżawy włączone zostały do Kodeksu Cywilnego Królestwa Polskiego regulacje zawarte w tytule VIII Kodeksu Napoleona (przy zachowaniu numeracji zawartej w Kodeksie); zob. Prawo cywilne obowiązujące w Królestwie Polskim, Warszawa 1914, s. 385-417; F. Longchamps, (w:) Encyklopedia prawa obowiązującego w Polsce, A. Peretiatkowicz (red.), Poznań 1925, s. 3-5.

12 Odpowiednio art. 1711 Kodeksu Cywilnego Królestwa Polskiego.

13 Według tłumaczenia z języka francuskiego zawartego w wersji Kodeksu Napoleona z 1813 r. dzierżawa określana była jako najem dziedzictw wiejskich; zob. Kodeks..., s. 422.

14 W oddziale I tytułu VIII Kodeksu Napoleona zawarte zostały zasady wspólne dla najmu domów i dóbr wiejskich, zaś w oddziale III - przepisy szczególne dla dzierżaw wiejskich.

15 Zob. Prawo cywilne obowiązujące..., op. cit., s. 392, 398-399.

16 Ustawa została przyjęta przez Sejm Rzeszy pod tytułem Księga ustaw cywilnych dla państwa niemieckiego i obowiązywała od dnia 1 stycznia 1900 r. Tak A. Ohanowicz, (w): Encyklopedia prawa..., op. cit., s. 149-151.

17 Tak brzmienie $\S 581$ zawarte w Niemiecki kodeks cywilny, tłum. W. Zieliński, Bytom 1900, s. 112-113.

18 Zob. kodeks zobowiązań ze skorowidzem rzeczowym, Warszawa 1958, s. 103-107; zob. też L. Górnicki, Prawo cywilne w pracach Komisji Kodyfikacyjnej RP w latach 1919-1939, Wrocław 2000, s. 397-455. 
dzierżawcy używanie i użytkowanie rzeczy lub prawa majątkowego, w szczególności prawo wytwarzania i pobierania pożytków przez czas oznaczony lub nieoznaczony za zapłatą umówionego czynszu ${ }^{19}$. Wymieniony akt prawny nie określał minimalnego czasu trwania najmu ${ }^{20}$. Natomiast dzierżawa zawarta na czas oznaczony, dłuższy niż 30 lat, po upływie tego terminu uważana była za zawartą na czas nieoznaczony.

System ochrony drobnych dzierżawców zapoczątkowała ustawa z dnia 3 lipca 1919 r. o ochronie drobnych dzierżawców ${ }^{21}$. Funkcjonował on do końca II Rzeczypospolitej $^{22}$. Ustawodawstwo ochronne obejmowało w zasadzie dzierżawy, których przedmiot stanowiły grunty o obszarze do 5 ha dla każdego dzierżawcy, jeżeli wydzierżawione zostały z majątku o obszarze ponad 45 ha. Aktem prawnym, który także poruszał problematykę drobnych dzierżawców, była ustawa z dnia 28 grudnia 1925 r. o wykonaniu reformy rolnej ${ }^{23}$.

Przemiany ustrojowe w pierwszym okresie Polski Ludowej wpłynęły na osłabienie znaczenia dzierżawy gruntów rolnych w stosunkach wiejskich ${ }^{24}$. Dekret Polskiego Komitetu Wyzwolenia Narodowego (PKWN) z dnia 6 września 1944 r. o przeprowadzeniu reformy rolnej ${ }^{25}$ zadecydował o przejęciu na własność państwa gruntów wielkiej własności, obejmując również grunty dzierżawione - od obszarników przez chłopstwo i bezrolnych ${ }^{26}$.

Na mocy art. 3 wspomnianego dekretu PKWN utworzony został Państwowy Fundusz Ziemi. Jego głównym zadaniem było dokonanie przebudowy ustroju rolnego. Stanowił wyodrębnioną administracyjnie masę majątkową obejmującą - obok innych składników - przede wszystkim nieruchomości rolne. Grunty wchodzące w skład tego funduszu były rozdysponowywane w sposób trwały, np. poprzez sprzedaż osobom fizycznym spełniającym warunki do ich nabycia ${ }^{27}$, albo w sposób tymczasowy, np. w formie przekazania w dzierżawę. Od czasu powstania Państwowe-

Zob. R. Longchamps de Berier, Polskie prawo cywilne, t. 2 - Zobowiązania, Lwów 1939, s. 502-504; A. Lichorowicz, Dzierżawa, (w:) System prawa prywatnego. Prawo zobowiązań - część szczegółowa, t. 8, J. Panowicz-Lipska (red.), Warszawa 2004, s. 155-157.

20 Zob. L. Domański, Instytucje kodeksu zobowiązań. Część szczegółowa, Warszawa 1938, s. 188-190.

21 Dz. Pr. P.P. nr 57, poz. 345. Moc obowiązywania wymienionego aktu prawnego była wielokrotnie przedłużana.

22 Tak W. Pańko, Dzierżawa..., op. cit., s. 166.

23 Dz.U. RP 1926, nr 1, poz. 1 z późn. zm.

24 A. Szemberg, Niektóre zagadnienia sytuacji ekonomicznej gospodarstw wielkotowarowych w rejonie środkowo-zachodnim, „Zagadnienia Ekonomiki Rolnej” 1958, nr 4, s. 72 i n.

25 Tekst jedn. Dz.U. z 1945 r. nr 3, poz. 13, z późn. zm.; zwany dalej: Dekret PKWN. Szerzej na temat Dekretu PKWN zob. np. W. Góra, Reforma rolna PKWN, Warszawa 1969, s. 15 i n.

26 Więcej na temat reformy rolnej: W. Pawlak, Prawo rolne PRL, cz. I - Przebudowa ustroju rolnego, Poznań 1968, s. 75-88; G. Tracz, Konsekwencje dekretu PKWN wobec ziemiaństwa a dzisiejsze rozumienie państwa prawa, „Forum Prawnicze” 2016, nr 5. Zob. też M. Korzycka, Kontekst historyczno-polityczny i naukowy normy konstytucyjnej o ustroju rolnym państwa polskiego, (w:) Państwo i prawo. Księga jubileuszowa 200-lecia Prokuratorii Generalnej RP, L. Bosek (red.), Warszawa 2017.

27 Zob. np. ustawę z dnia 12 marca 1958 r. o sprzedaży państwowych nieruchomości rolnych oraz uporządkowaniu niektórych spraw związanych z przeprowadzeniem reformy rolnej i osadnictwa rolnego; Dz.U. z 1958 r. nr 17, poz. 71 z późn. zm. 
go Funduszu Ziemi można dokonać podziału dzierżawy gruntów rolnych w Polsce na tzw. prywatną 28 oraz tzw. państwową. Ta pierwsza regulowana była początkowo przepisami kodeksu zobowiązań z 1933 r., a potem kodeksu cywilnego. Natomiast do dzierżawy z PFZ prócz wymienionych ustaw odnosiły się także zarządzenia i wytyczne Ministra Rolnictwa (przepisy resortowe) ${ }^{29}$.

Tworząc kodeks cywilny, ustawodawca założył - opierając się na panującej w tamtych czasach koncepcji likwidacji rolnictwa indywidualnego poprzez kolektywizację czy ,pegeeryzację" - że dzierżawa nie jest instrumentem wpływającym na właściwe wykorzystanie gruntów rolnych oraz poprawę struktury agrarnej $\mathrm{kraju}^{30}$. Stąd też tak niewiele przepisów w kodeksie cywilnym z dnia 23 kwietnia 1964 r. ${ }^{31}$ odnosi się bezpośrednio do dzierżawy gruntów rolnych.

W porównaniu z rozwiązaniami kodeksu zobowiązań zmianie uległa definicja dzierżawy. Co więcej, kodeks cywilny znacznie skrócił maksymalny czas trwania dzierżawy zawartej na czas oznaczony z 30 lat (art. 405 kz.) do 10 lat (art. 695 kc.). Ustawodawca zrezygnował też $\mathrm{z}$ części przepisów uwzględniających specyfikę dzierżawy gruntów rolnych, zawartych w kodeksie zobowiązań. Przykładowo, pominięto regulacje poświęcone zagadnieniu napraw (art. 408 kz.) oraz inwentarza żywego i martwego (art. 406, 407, 409 kz.), a także zagwarantowania ciągłości stosunku dzierżawy na wypadek śmierci wydzierżawiającego albo dzierżawcy (art. 391, w zw. z art. 403 kz.). Odrębnie w stosunku do kodeksu zobowiązań uregulowane zostały natomiast zasady wypowiedzenia dzierżawy na wypadek dopuszczenia się przez dzierżawcę opóźnienia w zapłacie czynszu. Takiej regulacji nie było w kodeksie zobowiązań (art. 703 kc.). Kodeks cywilny w wersji z 1964 r. nie przyznawał dzierżawcy prawa pierwokupu dzierżawionej nieruchomości rolnej. Dopiero w wyniku nowelizacji z dnia 26 października 1971 r. $^{32}$ dodany został $§ 2$ do art. 695 kc. poświęcony właśnie tej instytucji.

Jednym z kluczowych problemów w odniesieniu do zasobów gruntowych PFZ było zapewnienie ich właściwego wykorzystywania dla celów produkcji rolnej ${ }^{33}$. Przykładowy katalog zadań mających na celu podniesienie kultury rolnej określony

W artykule pojęć: dzierżawa gruntów rolnych tzw. prywatna oraz dzierżawa prywatnych gruntów rolnych używa się zamiennie.

29 Zob. W. Pańko, Dzierżawa gruntów rolnych w rolnictwie indywidualnym, (w:) Przemiany własności ziemi w rolnictwie polskim, A. Stelmachowski (red.), Wrocław - Warszawa - Kraków - Gdańsk 1974, s. 102.

30 Zob. A. Lichorowicz, Dzierżawa gruntów rolnych, (w:) Prawo rolne..., op. cit., s. 185. Analizując dane statystyczne z 1967 r. i 1972 r., stwierdzić należy, że nastąpił dynamiczny rozwój dzierżawy ziemi w porównaniu ze stanem panującym w latach pięćdziesiątych. W 1972 r. ziemia dzierżawiona stanowiła ponad 12\% w chłopskich użytkach rolnych. Średnio $27 \%$ gospodarstw użytkowało część areału w formie dzierżawy; zob. A. Szemberg, Dzierżawa ziemi w gospodarce indywidualnej w Polsce, „Zagadnienia Ekonomiki Rolnej” 1973, nr 3, s. 57- 66.

31 Tekst pierwotny Dz.U. z 1964 r. nr 16, poz. 93.

32 Dz.U. z 1971 r. nr 27, poz. 252.

33 Bliżej zob. M. Blażejczyk, Prawne aspekty racjonalnego wykorzystania gruntów Państwowego Funduszu Ziemi, „Studia Prawnicze” 1968, z. 18, s. 154; J. Pszczółkowski, O właściwe uregulowanie dzierżawy państwowych gruntów rolnych, „Państwo i Prawo” 1971, nr 1, s. 94-100. 
został w uchwale nr 347 Rady Ministrów z dnia 22 października 1963 r. w sprawie agrominimum $^{34}$. Formułowała ona tylko zalecenia, nie tworzyła zaś prawnych obowiązków w zakresie prawidłowego gospodarowania. Pod pojęciem ,agrominimum” należało rozumieć określone zabiegi agrotechniczne oraz zootechniczne, do których zaliczano m.in. uprawianie całego posiadanego lub użytkowanego areału ziemi, nadającego się do produkcji; wykonywanie podorywek po sprzęcie zbóż oraz orek przedzimowych; wapnowanie pól; stosowanie mechanicznego siewu zbóż; prawidłowe używanie nawozów mineralnych, wykonywanie racjonalnych zabiegów pielęgnacyjnych na łąkach i pastwiskach.

Na uwagę zasługują także Wytyczne Ministra Rolnictwa, Leśnictwa i Gospodarki Żywnościowej z dnia 1 lipca 1986 r. ${ }^{35}$ w sprawie wydzierżawiania i wynajmowania nieruchomości Państwowego Funduszu Ziemi ${ }^{36}$, do których wzór umowy dzierżawy stanowił załącznik nr 1 .

Wyboru dzierżawcy nieruchomości z PFZ organ wydzierżawiający dokonywał po zasięgnięciu opinii kółka rolniczego, a w przypadku, gdy w danej miejscowości nie było takowego - zebrania wiejskiego lub komitetu osiedlowego ${ }^{37}$. Trwałości stosunku prawnego dzierżawy służył przede wszystkim wymóg zawierania umowy dzierżawy w formie pisemnej na okres 10 lat.

Bardzo ważnym aktem prawnym dla rozwoju dzierżawy gruntów rolnych w Polsce jest niewątpliwie ustawa z dnia 19 października 1991 r. o gospodarowaniu nieruchomościami rolnymi Skarbu Państwa oraz o zmianie niektórych ustaw ${ }^{38}$. Na jej podstawie z dniem 1 stycznia 1992 r. rozpoczęła działalność Agencja Własności Rolnej Skarbu Państwa (potem ANR, obecnie KOWR), której głównym zadaniem było przejęcie wszystkich państwowych nieruchomości rolnych do Zasobu WRSP $^{39}$ oraz gospodarowanie tym zasobem na zasadach określonych we wspo-

34 Mon. Pol. nr 85, poz. 408. Zob. szerzej M. Błażejczyk, Prawne aspekty agrominimum, „Państwo i Prawo” 1964 z. 8-9, s. 240-251; M. Błażejczyk, Założenia prawnego unormowania ochrony gruntów rolnych, „Państwo i Prawo" 1968, z. 7-8, s. 77-78.

35 Nr GZUfz. 620-46/86/(niepublikowane). Zasady wydzierżawiania i wynajmowania nieruchomości PFZ były regulowane zarządzeniami Ministra Rolnictwa, jednak wobec stanowiska Naczelnego Sądu Administracyjnego, który stwierdził brak podstaw prawnych dla takich zarządzeń, ostatnie z nich zostało uchylone (Dz. Urz. Ministerstwa Rolnictwa, Leśnictwa i Gospodarki Żywnościowej z 1986 r. nr 2, poz. 6). W następstwie wydane zostały Wytyczne Ministra Rolnictwa, Leśnictwa i Gospodarki Żywnościowej z dnia 1 lipca 1986 r. Tak A. Stelmachowski, B. Zdziennicki, Prawo..., op. cit., s. 224.

36 Zwane dalej: Wytyczne z $1986 \mathrm{r}$.

37 Szerzej na temat wyboru dzierżawcy w świetle zarządzenia nr 103 Ministra Rolnictwa z dnia 19 czerwca 1981 r. w sprawie wydzierżawiania i wynajmowania nieruchomości Państwowego Funduszu Ziemi zob. W. Czechowicz, Wybór dzierżawców gruntów PFZ, „Nowe Rolnictwo” 1982, nr 5, s. 41-42.

38 Tekst pierwotny: Dz.U. z 1991 r. nr 107, poz. 464; zob. też A. Zieliński, Niektóre problemy gospodarowania państwowymi nieruchomościami rolnymi, (w:) Zagadnienia prawa cywilnego, samorządowego i rolnego. Pamięci Profesora W. Pańki, Katowice 1993, s. 54-60.

39 Do Zasobu WRSP przekazywane były sukcesywnie nieruchomości stanowiące własność państwa, które uprzednio wchodziły do Państwowego Funduszu Ziemi bądź stanowiły składnik zorganizowanych całości produkcyjnych w formie państwowych przedsiębiorstw gospodarki rolnej lub państwowych gospodarstw rolnych. 
mnianej ustawie oraz przepisach wykonawczych do tegoż aktu prawnego ${ }^{40}$. Przed 1992 r. dzierżawa gruntów rolnych polegała głównie na dodzierżawianiu nieruchomości w celu powiększenia areału istniejących już gospodarstw rolnych. Po 1992 r. stała się ona zaś podstawowym tytułem prawnym organizowania samodzielnych gospodarstw rolnych ${ }^{41}$, co wiązało się przede wszystkim z funkcjonowaniem AWRSP (obecnie KOWR) ${ }^{42}$. W pierwszym okresie prywatyzacji, na początku lat dziewięćdziesiątych, zrodziła się potrzeba szybkiego przekazania mienia państwowego podmiotom prywatnym w celu zapewniania ciągłości produkcyjnej. Wymieniona państwowa osoba prawna oddawała wtedy w dzierżawę duże powierzchnie gruntów rolnych ${ }^{43}$. Nie obowiązywały żadne limity obszarowe, co przyczyniło się do powstania wielu gospodarstw wielkoobszarowych. W następnych latach, wskutek zmiany polityki państwa w zakresie rolnictwa i oparcia ustroju rolnego na gospodarstwach rodzinnych, ANR zaczęła popierać przede wszystkim rozwój tychże gospodarstw.

\section{Regulacje prawne dotyczące dzierżawy gruntów rolnych}

Przepisy dotyczące samej umowy dzierżawy zawarte są w kodeksie cywilnym (art. 693-709 kc.). Mają one zastosowanie przede wszystkim do tzw. dzierżawy prywatnej. Z kolei do dzierżawy państwowej ${ }^{44}$ stosuje się również inne akty prawne, tj. ustawę z dnia 19 października 1991 r. o gospodarowaniu nieruchomościami rolnymi Skarbu Państwa ${ }^{45}$ oraz wydane na jej podstawie akty wykonawcze ${ }^{46}$. W przypadku najmu gruntów rolnych od jednostek samorządu terytorialnego, oprócz kodeksu cywilnego stosuje się także ustawę z dnia 21 sierpnia 1997 r. o gospodarce nieruchomościami $^{47}$ oraz ustawę z dnia 11 kwietnia 2003 r. o kształtowaniu ustroju rolnego. Obecnie obowiązująca regulacja prawna dzierżawy gruntów rolnych jest zatem zróżnicowana ${ }^{48}$. Na prowadzenie działalności na dzierżawionych gruntach rolnych wpływają również inne akty prawne, szczególnie te dotyczące ochrony gruntów rol-

40 Na temat AWRSP zob. np. S. Prutis, Struktury gospodarcze państwowej własności rolniczej, (w:) Prawo rolne, A. Stelmachowski (red.), Warszawa 2005, s. 181 i n, s. 204-205.

41 Zob. A. Lichorowicz, Pozycja prawna gospodarstw wielkotowarowych w polskim ustawodawstwie rolnym. Uwagi de lege lata, de lege ferenda, „Kwartalnik Prawa Prywatnego” 2003, z. 3, s. 599.

42 Po 1992 r. wzrosła także skala tzw. prywatnej dzierżawy gruntów rolnych, ale nie był to tak dynamiczny rozwój, jak w przypadku dzierżawy gruntów rolnych tzw. państwowej. Zob. L. Ostrowski, Międzysąsiedzkie dzierżawy gruntów rolnych w Polsce w latach 1991-1997, (w:) Dzierżawa ziemi jako czynnik przemian struktury agrarnej w Polsce, W. Ziętara (red.), Warszawa 1999, s. 89-103.

43 Zob. W. Ziętara, Dzierżawa nieruchomości rolnych z Zasobu Własności Rolnej Skarbu Państwa, (w:) Dzierżawa ziemi..., op. cit., s. 78-88.

44 Dzierżawa tzw. państwowa związana była z dzierżawą gruntów z Państwowego Funduszu Ziemi, a od 1992 r. z AWRSP (obecnie KOWR).

45 Zwana dalej ustawą z dnia 19 października 1991 r. albo ustawą o gospodarowaniu nieruchomościami rolnymi Skarbu Państwa.

46 Np. rozporządzenie Ministra Rolnictwa i Rozwoju Wsi z dnia 14 stycznia 2009 r. w sprawie szczegółowego trybu przeprowadzania przetargów na dzierżawę nieruchomości Zasobu Własności Rolnej Skarbu Państwa; rozporządzenie Ministra Rolnictwa i Rozwoju Wsi z dnia 1 sierpnia 2016 r. w sprawie sposobu ustalania wysokości czynszu dzierżawnego w umowach dzierżawy nieruchomości Zasobu WRSP.

48 Zob. np. A. Suchoń, J. Schürmann, Landpacht in Polen, Agrar - und Umweltrecht 2009, Heft 12, s. $377-381$. 
nych, związane z uzyskaniem przez dzierżawców środków unijnych oraz z podatkami.

Zasadniczym obowiązkiem wydzierżawiającego jest oddanie przedmiotu dzierżawy dzierżawcy, czyli umożliwienie mu używania gruntu i pobierania pożytków oraz niepodejmowanie działań, które mogłyby przeszkodzić w realizacji jego uprawnień ${ }^{49}$. Zarówno bowiem przy dzierżawie, jak i przy użytkowaniu, posiadanie odgrywa rolę decydującą. Uzyskanie władztwa nad rzeczą, i to w formie naturalnej dla prowadzenia bezpośredniej działalności produkcyjnej, jest celem obu tych instytucji prawnych ${ }^{50}$.

Przedmiot dzierżawy powinien być oddany w stanie zdatnym do umówionego lub zgodnego z właściwościami i przeznaczeniem użytku, a także utrzymany w takim stanie przez cały czas trwania dzierżawy. Uiszczanie czynszu jest podstawowym obowiązkiem dzierżawcy gruntów rolnych. Możliwość domagania się jego zapłaty przez wydzierżawiającego jest natomiast prawem tego ostatniego.

W świetle art. 696 kc. dzierżawca swoje prawo do używania przedmiotu dzierżawy i pobierania pożytków powinien wykonywać zgodnie $\mathrm{z}$ wymaganiami prawidłowej gospodarki. W kodeksie cywilnym nie ma bliższego określenia tych wymogów. Brak też podanych przykładowo działań, jakie dzierżawca winien podejmować w celu ich realizacji ${ }^{51}$. Zaznaczyć trzeba, że pojęcie ,prawidłowej gospodarki” występuje także w kilku innych przepisach kodeksu cywilnego. Artykuł 53 kc. i art. 213 kc. odsyłają do „zasad prawidłowej gospodarki”, natomiast w świetle art. 256 kc. użytkownik powinien wykonywać swoje prawo zgodnie z ,wymaganiami prawidłowej gospodarki”. Również te przepisy nie zawierają wyjaśnienia omawianego pojęcia.

Niewątpliwie tak ogólnie określone wymagania wobec dzierżawcy należy skonkretyzować w zależności od dziedziny gospodarczej. Inne będą wymagania w odniesieniu do pojedynczej działki dzierżawionego gruntu rolnego, inne do gospodarstwa rolnego jako zorganizowanej całości gospodarczej, a jeszcze inne do dzierżawy przedsiębiorstwa produkcyjnego czy usługowego.

Pewne wskazówki, a niekiedy nawet obowiązki, w zakresie prowadzenia prawidłowej gospodarki określone zostały w pozakodeksowych aktach prawnych. W odniesieniu do gruntów rolnych przede wszystkim trzeba wspomnieć o ustawie z dnia 3 lutego 1995 r. o ochronie gruntów rolnych ${ }^{52}$ regulującej zasady ochrony gruntów rolnych i leśnych oraz rekultywacji i poprawiania wartości użytkowej gruntów. Duża część zawartych w niej przepisów odnosi się zarówno do właściciela (użyt-

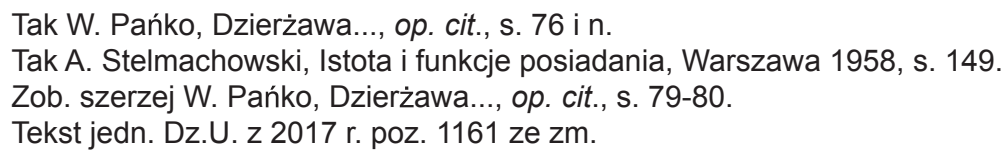


kownika wieczystego) nieruchomości, jak też posiadacza samoistnego i zależnego gruntu (np. dzierżawcy, dzierżyciela, zarządcy, administratora).

Pewne wskazówki dotyczące prowadzenia gospodarki na gruntach rolnych, w tym dzierżawionych, odnaleźć można w przepisach prawnych np. dotyczących płatności bezpośrednich. Przykładowo, rolnicy uprawnieni do płatności w ramach systemu płatności podstawowej muszą przestrzegać praktyk rolniczych korzystnych dla klimatu i środowiska.

\section{Dzierżawa gruntów rolnych a u.k.u.r.}

Wspomnieć należy także o innych regulacjach prawnych, które mogą mieć wpływ na obrót dzierżawny nieruchomościami rolnymi i możliwość nabywania gruntów na własność. Istotna zmiana, wynikająca ze zmienionej ustawy o kształtowaniu ustroju rolnego (która weszła w życie z dniem 30 kwietnia 2016 r.), stanowi (art. 2b ustawy), że nabywca nieruchomości rolnej jest zobowiązany prowadzić gospodarstwo rolne, w skład którego weszła nabyta nieruchomość rolna, przez okres co najmniej 10 lat od dnia nabycia przez niego tej nieruchomości, a w przypadku osoby fizycznej - prowadzić to gospodarstwo osobiście. W tym okresie nieruchomość nie może być zbyta ani oddana w posiadanie innym podmiotom. Jednocześnie ustawa określa, że sąd, na wniosek nabywcy nieruchomości rolnej, wyrazi zgodę na zawarcie umowy sprzedaży przed upływem okresu 10 lat od dnia przeniesienia własności tej nieruchomości, jeżeli konieczność jej dokonania wynika z przyczyn losowych, niezależnych od nabywcy. Wydaje się, że do takich przyczyn należy zaliczyć np. chorobę producenta rolnego. Sąd może zatem w takim przypadku wyrazić zgodę na dzierżawę, a potem - jeżeli właściciel chciałby sprzedać grunty dzierżawcy - na ich zbycie.

Oddane w dzierżawę czy sprzedane bez zgody sądu mogą być nieruchomości rolne, które zostały nabyte przed 30 kwietnia 2016 r., a także nieruchomości uzyskane od osób bliskich oraz w ramach dziedziczenia. Ustawy nie stosuje się do nieruchomości rolnych, które w dniu wejścia w życie ustawy, w ostatecznych decyzjach o warunkach zabudowy i zagospodarowania terenu są przeznaczone na cele inne niż rolne oraz do tych o powierzchni mniejszej niż 0,3 ha.

\section{Prawo pierwokupu dzierżawcy nieruchomości rolnych}

Przez kilkanaście lat prawo pierwokupu uregulowane było w art. $695 \S 1 \mathrm{kc}$. Od czasu wejścia w życie ustawy z dnia 11 kwietnia 2003 r. o kształtowaniu ustroju rolnego zagadnienie to zawarte jest $\mathrm{w}$ art. 3 ust. 1 tego aktu prawnego. W przypadku sprzedaży nieruchomości rolnej przez osobę fizyczną lub osobę prawną inną niż ANR (obecnie KOWR) prawo pierwokupu przysługuje z mocy ustawy jej dzierżaw- 
cy, jeżeli łącznie spełnione są następujące warunki: 1) umowa dzierżawy została zawarta $\mathrm{w}$ formie pisemnej i ma datę pewną oraz była wykonywana co najmniej 3 lata, licząc od tej daty; 2) nabywana nieruchomość wchodzi w skład gospodarstwa rodzinnego dzierżawcy lub jest dzierżawiona przez spółdzielnie produkcji rolnej. Artykuł uległ modyfikacji od 30 kwietnia 2016 r. Prawa pierwokupu pozbawiona została spółdzielnia produkcji rolnej.

Prawo pierwokupu zostało wyłączone w odniesieniu do nieruchomości położonych na obszarach przeznaczonych w planach zagospodarowania przestrzennego na cele inne niż rolne.

\section{Dzierżawa nieruchomości rolnych od KOWR}

Swoistym podmiotem wydzierżawiającym jest KOWR mająca status państwowej osoby prawnej. Jako struktura organizacyjna łączy ona w sobie cechy organu administracji gospodarczej (podmiotu prawa publicznego) oraz podmiotu gospodarczego działającego w skali kraju za pośrednictwem zróżnicowanych jednostek wykonawczych (oddziały terenowe, ekspozytury, gospodarstwa skarbowe) ${ }^{53}$. W świetle art. 5 ust. 1 ustawy z dnia 19 października 1991 r. Skarb Państwa powierza KOWR wykonywanie prawa własności i innych praw rzeczowych na jego rzecz w zakresie określonym przepisami. Uprawnienia wymienionej osoby prawnej odnośnie do gospodarowania mieniem Skarbu Państwa opierają się na konstrukcji prawnej powiernictwa. Powiernikiem jest osoba prowadząca cudze sprawy, lecz we własnym imieniu. KOWR nie staje się właścicielem przejętego mienia wchodzącego w skład Zasobu WRSP, a jedynie podmiotem wykonującym w imieniu własnym powierzone mu uprawnienia właścicielskie ${ }^{54}$. Biorąc pod uwagę, że wydzierżawiający nie musi być właścicielem przedmiotu dzierżawy, nie ma żadnych przeszkód, aby KOWR mogła oddawać w dzierżawę mienie wchodzące w skład wspomnianego zasobu.

Artykuł 39 ustawy o gospodarowaniu nieruchomościami rolnymi Skarbu Państwa stanowi, że umowę dzierżawy zawiera się po przeprowadzeniu przetargu ofert pisemnych lub publicznego przetargu ustnego. Artykuł 29 ust. 3-3c tego aktu prawnego dotyczący przetargów na sprzedaż nieruchomości rolnych stosuje się odpowiednio. W świetle powyższych przepisów KOWR może przeprowadzić przetarg

53 Tak S. Prutis, Struktury gospodarcze państwowej własności rolniczej, (w:) Prawo rolne..., op. cit., s. 177. Zob. też S. Prutis, R. Michałowski, Gospodarowanie Zasobem Własności Rolnej Skarbu Państwa, (w:) Prawo rolne, P. Czechowski (red.), Warszawa 2017, s. 335.

54 Polski porządek prawny nie zawiera ogólnych regulacji dotyczących instytucji powiernika. Zatem treść stosunku prawnego pomiędzy ANR a Skarbem Państwa określają przepisy ustawy z dnia 19 października 1991 r. Zob. szerzej A. Doliwa, Jeszcze w sprawie powierniczego statusu Agencji Własności Rolnej Skarbu Państwa, „Rejent” 2000, nr 2, s. 31-42; idem, Powierniczy charakter uprawnień Agencji Własności Rolnej Skarbu Państwa, „Studia luridica Agraria”, t. 1, Białystok 2000, s. 75-98; M. Możdżeń-Marcinkowski, Agencja Nieruchomości Rolnych, Zakamycze 2003, s. 68-93. Instytucja powiernictwa występuje w innych systemach prawnych, np. niemieckim i angielskim. Szeroka literatura na temat powiernictwa w wybranych państwach przedstawiona została w M. Możdżeń-Marcinkowski, Agencja Nieruchomości..., op. cit., s. 68-69. 
ofert pisemnych (konkurs ofert) na sprzedaż i odpowiednio na dzierżawę nieruchomości rolnych, w którym: mogą uczestniczyć wyłącznie podmioty, o których mowa w ust. $3 b$ art. 29. Są nimi z reguły rolnicy indywidualni (w rozumieniu przepisów o kształtowaniu ustroju rolnego), zamierzający powiększyć gospodarstwo rodzinne, jeżeli mają oni miejsce zamieszkania w gminie, w której położona jest nieruchomość wystawiana do przetargu lub w gminie graniczącej z tą gminą lub osoby posiadające kwalifikacje rolnicze określone w przepisach o kształtowaniu ustroju rolnego, zamierzające utworzyć gospodarstwo rodzinne w rozumieniu tych przepisów, lub członkowie rolniczych spółdzielni produkcyjnych postawionych w stan likwidacji lub upadłości, zamierzający utworzyć gospodarstwo rodzinne, lub spółki prawa handlowego, w których 100\% akcji albo udziałów należy do pracowników zlikwidowanych państwowych przedsiębiorstw gospodarki rolnej.

Przez wiele lat o wyborze dzierżawcy decydowała wysokość czynszu. W świetle zmienionej ustawy kryteriami wyboru najkorzystniejszej oferty mogą być w szczególności: a) odległość gospodarstwa rolnego oferenta od zbywanej nieruchomości zasobu (w odniesieniu do dzierżawy wydaje się zasadna odległość od oddanej w dzierżawę nieruchomości); b) powierzchnia nieruchomości rolnych nabytych lub wydzierżawionych z zasobu; c) intensywność produkcji zwierzęcej w gospodarstwie oferenta ${ }^{55}$.

Ustawa o gospodarowaniu nieruchomościami rolnymi Skarbu Państwa nie zawiera przepisów szczególnych normujących formę umów dzierżawy państwowych nieruchomości rolnych. W praktyce kontrakty takie zawierane są $\mathrm{w}$ formie pisemnej na podstawie wzorca umowy dzierżawy przygotowanego przez KOWR (dawna ANR). Umowy te podlegają rejestracji, a dane statystyczne odnoszące się do gruntów oddanych w dzierżawę publikowane są w comiesięcznym raporcie tej instytucji.

Ustawa z dnia 19 października $1991 \mathrm{r}$. wprowadziła możliwość przedłużenia umowy na następny okres dzierżawny. Jest to jednak odrębna instytucja w porównaniu z milczącym przedłużeniem dzierżawy przewidzianym w kodeksie cywilnym. W świetle art. 39 ust. 2 pkt 1 wymienionego aktu prawnego procedury przetargowej nie stosuje się m.in. wówczas, gdy dotychczasowy dzierżawca złożył ANR (obecnie KOWR) oświadczenie o zamiarze dalszego dzierżawienia nieruchomości na nowych warunkach uzgodnionych $\mathrm{z}$ wymienioną osobą prawną, z tym że czynsz nie może być niższy niż dotychczasowy. W sytuacji niezłożenia oświadczenia najpóźniej na trzy miesiące przed zakończeniem dzierżawy lub nieuzgodnienia nowych warunków umowy dzierżawy w terminie miesiąca od złożenia oświadczenia dzierżawa nie zostanie przedłużona ${ }^{56}$.

\footnotetext{
55 Szerzej A. Suchoń, Z aktualnej problematyki dzierżawy nieruchomości rolnych, „Przegląd Prawa Rolnego” 2016, nr 1, s. 49-64.

56 Zob. P. Iwaszkiewicz, Komentarz do art. 39 ustawy o gospodarowaniu nieruchomościami rolnymi Skarbu Państwa, (w:) P. Czechowski (red.), Ustawa o gospodarowaniu nieruchomościami rolnymi Skarbu Państwa. Komen-
} 
Problematyka przedłużania dzierżawy z KOWR zawarta jest obecnie w zarządzeniu nr 95/2017/Z Dyrektora Generalnego Krajowego Ośrodka Wsparcia Rolnictwa z dnia 6 października 2017 roku w sprawie wykonywania umowy dzierżawy nieruchomości Zasobu Własności Rolnej Skarbu Państwa ${ }^{57}$. Według niego „możliwe jest wydłużanie umów dzierżaw na okres np. do 15 lat - jeżeli dzierżawcą nieruchomości jest osoba prowadząca gospodarstwo rodzinne w rozumieniu przepisów o kształtowaniu ustroju rolnego albo osoba niemająca więcej niż 40 lat, jeśli nie spełnia wyłącznie wymogu dotyczącego 5-letniego osobistego prowadzenia gospodarstwa rolnego".

W odniesieniu do dzierżawy nieruchomości z Zasobu WRSP ustawa o gospodarowaniu nieruchomościami rolnymi Skarbu Państwa wprowadziła ograniczenia co do kodeksowych form określenia czynszu dzierżawnego. Według art. 39a ust. 2 tego aktu prawnego może on zostać wyrażony tylko na dwa sposoby: w postaci pieniężnej bądź jako równowartość pieniężna odpowiedniej ilości pszenicy. Strony umowy dzierżawy mogą jeden raz w trakcie jej trwania postanowić, że - poczynając od najbliższego terminu płatności - zmieniają dotychczasowy sposób regulowania czynszu: z opartego na cenie pszenicy na ustalany w kwocie pieniężnej.

Według rozporządzenia Ministra Rolnictwa i Rozwoju Wsi z dnia 1 sierpnia 2016 r. w sprawie sposobu ustalania wysokości czynszu dzierżawnego w umowach dzierżawy nieruchomości Zasobu WRSP, roczny czynsz dzierżawny od użytków rolnych ma być określony jako równowartość pieniężna ilości pszenicy określonej w tabelach stawek czynszu dzierżawnego od użytków rolnych, stanowiących załącznik do rozporządzenia, w zależności od rodzaju i klasy gruntów oraz miejsca ich położenia. Wysokość czynszu dzierżawnego dla gruntów ornych (dt pszenicy/ha) jest ustalana zgodnie z wytycznymi zawartymi w tabeli, biorąc pod uwagę okręg podatkowy oraz klasę gruntów ornych, np. dla IV okręgu podatkowego dla klasy IIIb wynosi ona 5,7 dt pszenicy, a dla IVb - 3,4 dt pszenicy/ha.

Dodatkowe rozwiązania korzystne dla dzierżawców w porównaniu do kodeksu cywilnego wprowadza także rozporządzenie Ministra Rolnictwa i Rozwoju Wsi z dnia 31 października 2017 r. w sprawie szczegółowych przesłanek odroczenia, rozłożenia na raty lub umorzenia należności Krajowego Ośrodka Wsparcia Rolnictwa oraz trybu postępowania w tych $\operatorname{sprawach}^{58}$. W $§ 2$ ust. 3 pkt 4 określa się, że należność (np. czynsz dzierżawny) może być umorzona w całości lub części, gdy prowadzone przez Krajowy Ośrodek Wsparcia Rolnictwa postępowanie wyjaśniające

tarz, Warszawa 2018, LEX SIP.

Zarządzenie nr 95/2017/Z Dyrektora Generalnego Krajowego Ośrodka Wsparcia Rolnictwa z dnia 6 października 2017 roku w sprawie wykonywania umowy dzierżawy nieruchomości Zasobu Własności Rolnej Skarbu Państwa [online]. KOWR (data dostępu: 20.12.2018). Dostępny w Internecie: <http://www.kowr.gov.pl/zasob/dzierzawa-nieruchomosci>. 
wykaże, iż: na skutek okoliczności, za które dzierżawca nie ponosi odpowiedzialności i które nie dotyczą jego osoby, zwykły przychód z przedmiotu dzierżawy uległ znacznemu zmniejszeniu w stopniu znacznie przewyższającym obniżenie wysokości czynszu dokonane na podstawie art. 700 kc., a zapłata należności byłaby związana z nadmiernymi trudnościami w odtworzeniu produkcji rolnej. Przepis art. $700 \mathrm{kc}$. przewiduje tylko, że w okolicznościach w nim wskazanych dzierżawca może żądać obniżenia czynszu przypadającego za dany okres gospodarczy.

Ustawa z dnia 19 października 1991 r. o gospodarowaniu nieruchomościami rolnymi przyznaje dzierżawcy prawo pierwszeństwa nabycia nieruchomości bez przetargu. Zgodnie z art. 29 ust. 1 tego aktu prawnego pierwszeństwo w nabyciu nieruchomości bez przetargu obecnie przysługuje przede wszystkim dzierżawcy zbywanej nieruchomości, jeżeli dzierżawa trwała faktycznie przez okres co najmniej trzech lat. KOWR (poprzednio ANR), po podjęciu decyzji o przeznaczeniu nieruchomości do sprzedaży, zobligowana jest na podstawie art. 28 ustawy z dnia 19 października 1991 r. do przygotowania wykazu bez względu na to, czy nieruchomości będą sprzedane bez przetargu, czy też w trybie przetargowym. Następnie sprawdza, czy istnieją podmioty, którym przysługuje prawo pierwszeństwa nabycia nieruchomości bez przetargu ${ }^{59}$.

Ustawa z dnia 14 kwietnia 2016 r. o wstrzymaniu sprzedaży nieruchomości z Zasobu Własności Rolnej Skarbu Państwa oraz o zmianie niektórych ustaw ${ }^{60}$ stanowi, że minister właściwy do spraw rozwoju wsi na wniosek Dyrektora Generalnego KOWR może wyrazić zgodę na sprzedaż nieruchomości lub ich części, innych niż wymienione w ust. 1 (czyli np. o powierzchni 2 ha i więcej), jeżeli jest to uzasadnione względami społeczno-gospodarczymi.

\section{Nowy model dzierżawy rolniczej - wnioski de lege ferenda}

Konieczność rozbudowy przepisów dotyczących omawianej instytucji prezentowało w swoich opracowaniach wielu autorów. Wspomnieć trzeba przede wszystkim o A. Lichorowiczu ${ }^{61}$, W. Pańko ${ }^{62}$, C. Stempce-Jaźwińskiej ${ }^{63}$ czy A. Suchoń ${ }^{64}$. Wielokrotnie podejmowane były próby stworzenia nowych przepisów poświęco-

59 Oczywiście w sytuacji, gdy nieruchomość nie została sprzedana bez przetargu podmiotom wymienionym w art. 17. ust. 1, art. $17 \mathrm{~b}$ ust. 4 oraz art. 42 ustawy z dnia 19 października $1991 \mathrm{r}$.

60 Dz.U. z 2016 r., poz. 585 ze zm., dalej: ustawa z dnia 14 kwietnia 2016 r.

61 Zob. zwłaszcza A. Lichorowicz, O nowy model dzierżawy rolniczej (propozycje zmian aktualnej regulacji prawnej dzierżaw rolnych), (w:) Dzierżawa ziemi jako czynnik przemian..., op. cit., s. 186-196; A. Lichorowicz, Potrzeba prawnego uregulowania dzierżawy rolnej w Polsce (na podstawie doświadczeń krajów Unii Europejskiej), „Przegląd Prawa Rolnego" 2010, nr 2, s. 63 i n.

62 Zob. W. Pańko, Dzierżawa..., op. cit., s. 231-233.

63 Zob. C. Stempka-Jaźwińska, Umowa dzierżawy nieruchomości, Toruń 1981, s. 164-191.

64 A. Suchoń, Prawna ochrona trwałości gospodarowania na dzierżawionych gruntach rolnych, Poznań 2006, s. 259-272; idem, Jeszcze o potrzebie prawnego uregulowania dzierżawy rolniczej w Polsce, „Przegląd Prawa Rolnego" 2016, nr 1. 
nych dzierżawie gruntów rolnych. Powyższy postulat nie stracił na aktualności, ale z uwagi na zmiany społeczno-gospodarcze potrzeba podjęcia dyskusji wzrosła. Zwróciła na to szczególną uwagę Komisja Rolnictwa i Rozwoju Wsi, składając w lutym 2015 r. do Sejmu ${ }^{65}$ projekt ustawy o dzierżawie rolniczej. Zasadne zatem wydaje się podjęcie prac legislacyjnych w tym zakresie. Tworząc nowy model dzierżawy gruntów rolnych, należy nawiązać do dorobku legislacyjnego krajów zachodnioeuropejskich oraz skorzystać z doświadczeń KOWR.

Regulacja dzierżawy gruntów rolnych jest niedostosowana do aktualnych potrzeb obrotu dzierżawnego. Co więcej, z uwagi na przemiany polityczne i gospodarcze oraz członkostwo w Unii Europejskiej, coraz większe znaczenie z punktu widzenia zachowania trwałości gospodarowania na dzierżawionych gruntach rolnych mają instrumenty ekonomiczne. Przepisy prawne nie zawsze są korzystne dla dzierżawców w kontekście prowadzonej przez nich działalności rolniczej. Ponadto dzierżawcy często nie spełniają ustawowych warunków, aby skorzystać z instytucji ułatwiających im nabycie własności dzierżawionych gruntów rolnych. Ustawodawca polski zbyt mało uwagi poświęca ochronie działalności rolniczej prowadzonej na dzierżawionych gruntach rolnych.

Jak podkreślił A. Lichorowicz, w wielu krajach zaobserwować można trend tworzenia szczególnego statusu prawnego dzierżawcy gruntów rolnych. Jego nabycie przez producenta rolnego, uwarunkowane jednak spełnieniem wielu ustawowo określonych wymogów, powoduje korzystanie przez dzierżawcę z uprzywilejowanej ochrony prawnej, a także świadczeń socjalnych ${ }^{66}$.

\section{Podsumowanie}

Instytucja dzierżawy na trwałe wpisuje się w rozwój i ewolucję prawa rolnego. W poszczególnych okresach $\mathrm{w}$ dużym stopniu na kształtowanie się regulacji prawnych dotyczących instytucji dzierżawy gruntów rolnych oddziaływały czynniki polityczne, ekonomiczne i społeczne. Świadczy o tym choćby wydanie przepisów chroniących drobnych dzierżawców w okresie międzywojennym czy też mało rozbudowany katalog instrumentów ochrony trwałości dzierżawy gruntów rolnych w kodeksie cywilnym z 1964 r. Ten ostatni był wynikiem panującej w tamtych czasach koncepcji likwidacji rolnictwa indywidualnego poprzez kolektywizację czy „pegeeryzację". Jak zostało podkreślone w trakcie rozważań, od czasu powstania Państwowego Funduszu Ziemi można dokonać podziału dzierżawy gruntów rolnych w Polsce na tzw. prywatną oraz tzw. państwową. Ta pierwsza regulowana była początkowo przepisami kodeksu zobowiązań z 1933 r., a potem kodeksu cywilnego.

65 A. Suchoń, Jeszcze o potrzebie prawnego..., op. cit., s. 243 i n.

66 Tak A. Lichorowicz, Potrzeba prawnego uregulowania..., s. 69 i n. 
Natomiast do dzierżawy z PFZ, prócz wymienionych ustaw, odnosiły się także zarządzenia i wytyczne Ministra Rolnictwa (przepisy resortowe) ${ }^{67}$.

Przemiany, jakie nastąpiły w Polsce po 1990 r., wpłynęły również na dzierżawę. Szczególne znaczenie miało uchwalenie ustawy z dnia 19 października 1991 r. i utworzenie AWRSP (obecnie KOWR). Natomiast członkostwo Polski w Unii Europejskiej wpłynęło na coraz większe zainteresowanie naszego ustawodawcy prawnymi gwarancjami ochrony zdolności produkcyjnej przedmiotu dzierżawy. Wynika to $\mathrm{z}$ jednej strony z konieczności dostosowania prowadzonej działalności rolniczej do standardów unijnych, z drugiej zaś prowadzenia jej z uwzględnieniem wymogów ochrony środowiska. Członkostwo w Unii Europejskiej spowodowało objęcie naszego państwa Wspólną Polityką Rolną, co łączy się z uzyskaniem dostępu do znacznych środków finansowych z budżetu unijnego. Na prowadzenie stabilnej działalności rolniczej na dzierżawionych gruntach rolnych w nowych warunkach politycznych i gospodarczych wpływają w coraz większym stopniu instrumenty ekonomiczne związane z udzielaniem płatności unijnych. Są one związane z procedurą administracyjną i funkcjonowaniem Agencji Restrukturyzacji i Modernizacji Rolnictwa.

W porównaniu z dzierżawą prywatnych gruntów rolnych swoboda stron w zakresie zawierania umowy dzierżawy nieruchomości z Zasobu WRSP, ustalania jej warunków i wykonywania została w dużym stopniu ograniczona. Co więcej, oprócz powszechnie obowiązującego prawa istotny wpływ na dzierżawę nieruchomości z Zasobu WRSP mają zarządzenia Dyrektora Generalnego KOWR, a kiedyś wytyczne Prezesa ANR. Dzierżawa jest jednak nadal umową cywilnoprawną, regulowaną przepisami prawa cywilnego a nie umową administracyjnoprawną.

Należy również wskazać, że na wykonywanie dzierżawy gruntów rolnych, także tej prywatnej, wpływają przepisy prawa administracyjnego. Do tych ostatnich zaliczyć można m.in. uwłaszczenie dzierżawców z 1971 r., ulgi i zwolnienia w podatku rolnym, obowiązki dzierżawcy w zakresie prowadzenia prawidłowej gospodarki na dzierżawionym gruncie rolnym, wynikające z przepisów poświęconych ochronie gruntów rolnych i leśnych (ich nieprzestrzeganie może łączyć się z określonymi sankcjami administracyjnymi) czy płatnościom unijnym (szczególnie system płatności bezpośrednich). Należy jednak podkreślić, że dzierżawa pozostaje nadal umową cywilnoprawną. 
LEASE AS A POPULAR INSTITUTION OF PRIVATE LAW IN AGRICULTURE - HISTORICAL REMARKS, CURRENT STATUS AND DEVELOPMENT PROSPECTS

Keywords: lease, farm, agricultural land

The lease, along with ownership, is the legal title of running and organizing farms. The purpose of the article is, first of all, to present the formation of legal regulations concerning the agricultural land lease and factors affecting this process and, secondly, to determine how the conclusion and execution of leases as a civil law institution is affected by the fact that the National Agricultural Support Center is a state legal person.

The article begins with the presentation of the evolution and development of the lease regulations, referring to the Napoleon Code, the Code of Obligations of 1934 and the system of protection of small lessees in the interwar period. Then, the Author points out that since the State Land Fund was established, it has been possible to categorize the lease of agricultural land in Poland into, so-called, private and state one. Subsequently, the paper focuses on the Act of 19 October 1991 on the management of agricultural property of the Treasury, implementing regulations to this Act and the regulations of the General Director of National Agricultural Support Center.

In the summary, the Author states that the lease has become an integral element of the development and evolution of agricultural law. In particular periods, political, economic and social factors influenced, to a large extent, the formation of legal regulations concerning the agricultural land lease. In comparison with the lease of private agricultural lands, the parties' freedom to conclude an agreement for lease of real estate from the Agricultural Property Stock of the State Treasury, to determine its conditions and performance has been largely limited. Nevertheless, lease remains a civil law contract.

\section{Bibliografia:}

Bardach J., Leśnodorski B., Pietrzak M., Historia państwa i prawa polskiego, Warszawa 1976.

Błażejczyk M., Prawne aspekty agrominimum, „Państwo i Prawo” 1964, z. 8-9.

Błażejczyk M., Prawne aspekty racjonalnego wykorzystania gruntów Państwowego Funduszu Ziemi, „Studia Prawnicze”, z. 18.

Błażejczyk M., Założenia prawnego unormowania ochrony gruntów rolnych, „Państwo i Prawo” 1968, z. 7-8.

Czechowicz W., Wybór dzierżawców gruntów PFZ, „Nowe Rolnictwo” 1982, nr 5.

Doliwa A., Jeszcze w sprawie powierniczego statusu Agencji Własności Rolnej Skarbu Państwa, „Rejent" 2000, nr 2. 
Doliwa A., Powierniczy charakter uprawnień Agencji Własności Rolnej Skarbu Państwa, „Studia Iuridica Agraria", t. 1, Białystok 2000.

Domański L., Instytucje kodeksu zobowiązań. Część szczegółowa, Warszawa 1938.

Góra W., Reforma rolna PKWN, Warszawa 1969.

Górnicki L., Prawo cywilne w pracach Komisji Kodyfikacyjnej RP w latach 1919-1939, Wrocław 2000.

Iwaszkiewicz P., Komentarz do art. 39 ustawy o gospodarowaniu nieruchomościami rolnymi Skarbu Państwa, (w:) P. Czechowski (red.), Ustawa o gospodarowaniu nieruchomościami rolnymi Skarbu Państwa. Komentarz, Warszawa 2018, LEX SIP.

Korzycka M., Kontekst historyczno-polityczny i naukowy normy konstytucyjnej o ustroju rolnym państwa polskiego, (w:) Państwo i prawo. Księga jubileuszowa 200-lecia Prokuratorii Generalnej RP, L. Bosek (red.), Warszawa 2017.

Lichorowicz A., Dzierżawa, (w:) System prawa prywatnego. Prawo zobowiązań - część szczegółowa, Tom 8, J. Panowicz-Lipska (red.), Warszawa 2004.

Lichorowicz A., Instrumenty oddziaływania na strukturę gruntową Polski w ustawie z dnia 11 kwietnia 2003 r. o kształtowaniu ustroju rolnego, „Kwartalnik Prawa Prywatnego” 2004, nr 2.

Lichorowicz A., O nowy model dzierżawy rolniczej (propozycje zmian aktualnej regulacji prawnej dzierżaw rolnych), (w:) Dzierżawa ziemi jako czynnik przemian struktury agrarnej w Polsce, W. Ziętara (red.), Warszawa 1999.

Lichorowicz A., Potrzeba prawnego uregulowania dzierżawy rolnej w Polsce (na podstawie doświadczeń krajów Unii Europejskiej), „Przegląd Prawa Rolnego” 2010, nr 2.

Lichorowicz A., Pozycja prawna gospodarstw wielkotowarowych w polskim ustawodawstwie rolnym. Uwagi de lege lata, de lege ferenda, „Kwartalnik Prawa Prywatnego” 2003, z. 3.

Lipowicz I., Prawne formy działania administracji publicznej - między stabilizacją a potrzeba przełomu, „Ruch Prawniczy, Ekonomiczny i Socjologiczny” 2016, z. 4.

Longchamps F., (w:) Encyklopedia prawa obowiązującego w Polsce, A. Peretiatkowicz (red.), Poznań 1925.

Longchamps de Berier R., Polskie prawo cywilne, t. 2 - Zobowiązania, Lwów 1939.

Łętowski J., Umowy, pertraktacje, uzgodnienia, „Rzeczpospolita” z dnia 18 listopada 1993.

Możdżeń-Marcinkowski M., Agencja Nieruchomości Rolnych, Zakamycze 2003.

Ostrowski L., Międzysąsiedzkie dzierżawy gruntów rolnych w Polsce w latach 1991-1997, (w:) Dzierżawa ziemi jako czynnik przemian struktury agrarnej w Polsce, W. Ziętara (red.), Warszawa 1999.

Pańko W., Dzierżawa gruntów rolnych w rolnictwie indywidualnym, (w:) Przemiany własności ziemi w rolnictwie polskim, A. Stelmachowski (red.), Wrocław - Warszawa - Kraków - Gdańsk 1974.

Pańko W., Dzierżawa gruntów rolnych, Warszawa 1975.

Pawlak W., Prawo rolne PRL, cz. I - Przebudowa ustroju rolnego, Poznań 1968.

Prutis S., Instytucje podstawowe prawa prywatnego, Białystok 2018.

Prutis S., Struktury gospodarcze państwowej własności rolniczej, (w:) Prawo rolne, A. Stelmachowski (red.), Warszawa 2005.

Prutis S., Michałowski R., Gospodarowanie Zasobem Własności Rolnej Skarbu Państwa, (w:) Prawo rolne, P. Czechowski (red.), Warszawa 2017. 
Pszczółkowski J., O właściwe uregulowanie dzierżawy państwowych gruntów rolnych, „Państwo i Prawo" 1971, nr 1 .

Sójka-Zielińska K., Wielkie kodyfikacje cywilne XIX wieku, Warszawa 1970.

Stelmachowski A., Istota i funkcje posiadania, Warszawa 1958.

Stelmachowski A., Zdziennicki B., Prawo rolne, Warszawa 1987.

Suchoń A., Jeszcze o potrzebie prawnego uregulowania dzierżawy rolniczej w Polsce, „Przegląd Prawa Rolnego" 2016, nr 1.

Suchoń A., Prawna ochrona trwałości gospodarowania na dzierżawionych gruntach rolnych, Poznań 2006.

Suchoń A., Z aktualnej problematyki dzierżawy nieruchomości rolnych, „Przegląd Prawa Rolnego” 2016, nr 1 .

Suchoń A., Schurmann J., Landpacht in Polen, Agrar - und Umweltrecht 2009, Heft 12.

Szemberg A., Dzierżawa ziemi w gospodarce indywidualnej w Polsce, ,Zagadnienia Ekonomiki Rolnej" 1973, nr 3.

Szemberg A., Niektóre zagadnienia sytuacji ekonomicznej gospodarstw wielkotowarowych w rejonie środkowo-zachodnim, „Zagadnienia Ekonomiki Rolnej” 1958, nr 4.

Tańska-Hus B., Dzierżawa rolnicza jako instrument przekształceń strukturalnych w rolnictwie, Wrocław 2000.

Tracz G., Konsekwencje dekretu PKWN wobec ziemiaństwa a dzisiejsze rozumienie państwa prawa, „Forum Prawnicze” 2016, nr 5.

Wierzbowski M. (red.), Prawo administracyjne, wyd. 12, Warszawa 2015.

Zieliński A., Niektóre problemy gospodarowania państwowymi nieruchomościami rolnymi, (w:) Zagadnienia prawa cywilnego, samorządowego i rolnego. Pamięci Profesora W. Pańki, Katowice 1993.

Ziętara W., Dzierżawa nieruchomości rolnych z Zasobu Własności Rolnej Skarbu Państwa, (w:) Dzierżawa ziemi jako czynnik przemian struktury agrarnej w Polsce, W. Ziętara (red.), Warszawa 1999. 